\title{
Telling the Untellable: Negotiating Maternal Bereavement in Sophie Daull's Camille, mon envolée (2015)
}

\author{
Julie Rodgers
}

\section{Introduction}

It is only during the course of the twentieth century that the loss of a child became a rare event. As Parkes and Prigerson point out, evidence suggests that 'during earlier days $[. .$.$] most parents expected$ to lose up to half their children in infancy or childhood' and, in addition to this, 'they accepted their losses more readily than we do today'. ${ }^{1}$ However, whether it is due to our increased unpreparedness for such an event as a result of medical advances that have succeeded in greatly lowering infant and child death rates, or the fact that fewer children are being born to families nowadays thus possibly creating more intense parent-child bonds, it is now widely acknowledged in bereavement studies that the death of a child is a loss unlike any other. As Josette Gril notes, 'Il est indéniable que le deuil de l'enfant occupe une place bien spécifique dans le vécu de la douleur, ce qui lui confrère un statut particulier qui ne transparaît pas dans la théorie classique du deuil'. ${ }^{2}$ Possibly the most distressing type of death that one may ever encounter, parental grief has been recorded in bereavement texts as traumatic, chaotic, overwhelming and alienating. ${ }^{3}$ For Julia Samuel it is frightening and confusing, like

1. Colin Murray Parkes and Holly G. Prigerson, Bereavement: Studies of Grief in Adult Life (London: Routledge, 2010), p. 143.

2. Josette Gril, Vivre après la mort de son enfant (Paris: Albin Michel, 2007), p. 5.

3. Catherine Seigal, Bereaved Parents and Their Continuing Bonds (London: Harper Collins, 2017), p. 10. 
'falling into a fathomless hole' or being 'thrown into an alien world' and, moreover, 'of all the losses people suffer, it takes the longest to rebuild their lives afterwards'. ${ }^{4}$ It is little wonder then that parents who lose a child often report the inadequacy of the standard language of mourning and prescribed models of grief to express the uniqueness of their pain and help them navigate their loss, with the stages of their bereavement being less predictable than in other instances of death and the point of final resolution much more difficult to achieve. ${ }^{5}$ Indeed, many would argue that there is no completion of the grief process when it relates to the loss of a child but, rather, it is an ongoing bereavement that results more in adjustment than acceptance. ${ }^{6}$ Perhaps one of the most challenging aspects of child death is that it causes a sense of 'wrongness' in the natural order. As Linda Edelstein remarks:

There is rarely a 'right' time for anyone to die, and certainly not a child. But if there is an order or a rightness, then it is more justifiable that the oldest die first. It touches people's basic hope of 'fair play' and an orderliness to life and death. Death is playing the game fairly. Rationality prevails - this comforts the survivor. The death of a child goes counter to the rules about death. ${ }^{7}$

If the death of the child is sudden and unexpected then the already devastating loss is rendered even more traumatic, with no period of anticipation and rehearsal when parents can begin to acclimate

4. Julia Samuel, Grief Works: Stories of Life, Death and Surviving (London: Penguin Life, 2018), p. 185.

5. Celia Hindmarch, On the Death of a Child, (Oxford: Radcliffe, 2009), pp. 30-31.

6. See Dennis Klass, 'The Deceased Child in the Psychic and Social Worlds of Bereaved Parents', Death Studies, 21.2 (1997), 147-76 for a full discussion of the enduring and complex nature of parental grief.

7. Linda Edelstein, Maternal Bereavement: Coping with the Unexpected Death of a Child (New York: Praeger, 1984), p. 44. 
themselves to the impending loss. ${ }^{8}$ Another factor, Edelstein argues, that can further shape the nature of the grief experienced relates to the status of the parent as either mother or father of the deceased child. Without wishing to diminish the father's bereavement, Edelstein states that is important to acknowledge the specificity of maternal grief which she sees as being impacted by the uniqueness of the mother-child dyad and, in particular, the fact that the child once shared the mother's body. ${ }^{9}$ Edelstein is not the only bereavement scholar to highlight a difference between maternal and paternal grief. Samuel observes that 'mothers tend to be preoccupied with the loss of their child for longer than men' and exhibit 'higher levels of anxiety, intrusive thoughts, and disrupted sleep'. ${ }^{10}$ Parkes and Prigerson also note that 'on the whole, women seem to be more vulnerable to the loss of a child than men' ${ }^{11}$ while Davidson and Stahls remark that such is the profoundness of maternal grief that even 'mothers themselves are surprised by its depth and intensity'.

Many of these defining features of parental grief discussed so far emerge in Camille, mon envolée, the novel selected for analysis in this article. ${ }^{13}$ For example, this sense of 'wrongness' and 'untimeliness' in relation to the death of a child is expressed by the mother-narrator who, although witnessing first-hand the rapid and worrying demise of her daughter's physical state, refuses to accept that the illness will culminate in tragedy, for it would be illogical,

8. For further insight into the intensity of sudden parental grief as opposed to the loss of a child in more understandable and acceptable, see Miriam J. Anderson et al., 'Psychological and Religious Coping Strategies of Mothers Bereaved by the Sudden Death of a Child', Death Studies, 29.9 (2005), 811-26.

9. Edelstein, Maternal Bereavement, p. 54.

10. Samuel, Grief Works, p. 187.

11. Parkes and Prigerson, Bereavement, p. 143.

12. Deborah Davidson and Helena Stahls, 'Maternal Grief: Creating an Environment for Dialogue' in Journal of the Motherhood Initiative for Research and Community Involvement, 1.2 (2010), 16-25 (p. 16).

13. Sophie Daull, Camille, mon envolée (Paris: Philippe Rey, 2015), hereafter CME in the text. 
'une enfant de 16 ans ne meurt pas' (CME 37-38). The unresolvable nature of parental grief mentioned above is also highlighted in the novel. The mother-narrator describes her bereavement as 'le cyclone pour toujours' ( $C M E 47)$ and of her daughter proclaims 'Toi disparue n'a pas de fin' (CME 118). However, the parental bereavement process, already traumatic in and of itself, is further complicated in Camille, mon envolée by the two additional factors that have already been signposted, that is, the suddenness and unexpectedness of the daughter's death and the particularity of the maternal experience. This article will offer a close reading of the experience of the loss of a child as recounted by the mother-narrator of Camille, mon envolée with a specific focus on the impact of the death of the daughter on maternal subjectivity. The article will examine the physical, psychological and social consequences of child death for the mother, which will, in turn, lead to a positioning of the experience of maternal bereavement as one that is overwhelmingly embodied in nature. In a final section, the article will discuss the role of writing in the difficult, complicated and, at times, untellable negotiation of maternal loss and the potential of Camille, mon envolée to both expand on and challenge our assumptions of maternal grief.

\section{Background to the text}

Camille, mon envolée, published by Éditions Philippe Rey in 2015, marks the entry of Sophie Daull, an established actress in France, into the literary scene. The text is presented and marketed as a novel by its publishing house, but the precise nature of its form is much more complex and encompasses a wide range of genres from autofiction to letter writing and the journal intime. Camille, mon envolée recounts the real-life event of the sudden death of Daull's only daughter (and, indeed, only child) at the age of sixteen due to an undiagnosed and rapidly spreading bacterial infection. This is not the first time that Daull has had to deal with the devastating loss of an immediate family member as in 1985 she was the one to discover the body her 
mother who had been brutally murdered by her ex-partner. There are many references to this earlier tragedy throughout Camille, mon envolée and it is not insignificant to note that shortly after publishing the account of her daughter's death, Daull felt propelled to return to this older trauma, leading to the publication just one year later of $L a$ Suture (2016) and then again with her most recent novel $A u$ grand lavoir (2018) ${ }^{14}$ In both of these subsequent texts, Daull revisits the grief experienced at the double loss of her mother and daughter and continues to probe the questions of how to live alongside and in dialogue with the deceased. It is not unusual for Camille, mon envolée to have triggered further writing on grief and mourning. As Barbara Rosoff notes, 'your child's death sets off resonances of other significant losses in your life', pushing emotional residue and unresolved feelings to the surface.

With writing commencing mere days after the daughter's death, Camille, mon envolée presents us with the most immediate and acute stage of bereavement, depicting the full gamut of turbulent emotions experienced at this time - shock, pain, chaos, despair, guilt, anger and emptiness. Surprisingly, and perhaps disturbingly so for some readers, Daull manages to do this in a tone that is humorous and measured, despite the fact there has been very little distance or time for recovery between the events themselves and the action of recounting them. Structurally, Camille, mon envolée is an interesting text in that it has a double time frame: first, the time frame of the daughter's illness and death which endures four days and, second, the writing time frame which is approximately four months. To clarify, there is to-and-fro movement in the text between both time frames which are distinguished by section divisions and a font difference. It should be mentioned here that Camille's death occurs on 23 December, hence all the preparations for the Christmas holidays are

14. Sophie Daull, La Suture (Paris: Philippe Rey, 2016) and Au grand lavoir (Paris: Philippe Rey, 2018).

15. Barbara Rosoff, The Worst Loss: How Families Heal from the Death of a Child (New York: Henry Holt, 1994), p. 99. 
already in place both in the family home and in the outside world while this trauma is unfolding. This particular backdrop of festivity magnifies the suffering of the mother-narrator as it cruelly juxtaposes her loss against a world that continues to operate regardless, forcing her to witness joy and celebration, to move forward with the flow of the present, while at the same time trying to grapple with bereavement: 'Quarante-huit heures déjà que tu est morte; et la terre continuait de tourner toute hérissée de sapins enguirlandés' (CME 93).

The title of the novel is curious in that it suggests the passing of the daughter as celestial and transcendental when, in fact, Camille's struggle to survive is ugly and visceral and by no means a gentle transition into the afterlife. What the idea of 'envoler' does capture however is the mother's sense of powerlessness when confronted with her daughter's impending death. This sense of failure is common to parents who lose a child, but particularly mothers who feel that protection is intrinsic to their maternal duty. As Roszika Parker observes, the original responsibility that is instilled in the expectant mother to keep the defenceless foetus alive in the womb unfurls into the maternal experience to the extent that the mother often feels solely responsible for the life and death of the child. Hence, the passing of a child mobilizes a deep-rooted maternal anxiety and guilt that the mother has not fulfilled her role. ${ }^{16}$ Edelstein makes a similar observation, stating that mothers who lose a child feel that they were 'unable to guide their children into adulthood and unable to protect them from dying prematurely. The failure results in lowered selfesteem because they blame themselves for all that they did not do., 17 Subsequently, Daull wonders if Camille's death could have been avoided, not necessarily due to better intervention on the part of the medical services but, rather, if she had been insistent, had trusted her 'maternal' instinct ( $C M E$ 91). The narrator laments, 'Pourquoi moi,

16. Roszika Parker, Torn in Two (London: Virago, 2005), p. 12.

17. Edelstein, Maternal Bereavement, p. 39. 
qui t'ai donné la vie, n'ai-je pas compris qu'on te la retirait?' (CME 137). An interesting link back is made with a previous abortion that she had before Camille's birth and she compares Camille's death to a second abortion, an abortion of her future (CME 150). This reference to abortion implies a feeling of maternal responsibility but also reminds one of Rosoff's observation mentioned earlier on in the article of one loss triggering memories of another. Given the weight of the maternal guilt, it is not surprising that one of the main motivations for writing the novel stems from a necessity on the part of the mother to restore life to the daughter - 'Je vais inaugurer ton outre-vie' (CME 12) - and to compensate for it is felt as maternal failure - 'Je te le dois' (CME 12).

\section{Maternal bereavement: physical manifestations}

Moving on from these initial observations on the sense of responsibility felt by the mother in relation to the child's life, the article will now engage in a more in-depth analysis of the specificity of maternal bereavement in terms of its physicality, its emotional impact and its reconfiguration of the mother in society. First of all, to return to Edelstein, the death of a child launches an assault on maternal identity and self-esteem and causes the mother to relinquish a part of who she is. This loss of self that is experienced by the mother, Edelstein informs us, is undoubtedly related to the "shared physical attachment during pregnancy, a symbiotic attachment during the child's infancy, and the ever-present adjustments and absorption during the years of mothering. ${ }^{18}$ The care work of mothering and investment of the mother's identity in the child, Edelstein purports, are so great that the physical death of a child leads to a symbolic death of the mother. ${ }^{19}$ It is not surprising, therefore, that Daull's

18. Edelstein, Maternal Bereavement, p. 126.

19. Edelstein, Maternal Bereavement, p. 126. 
maternal body should present similar symptoms to the daughter's agony. As Daull tends to her rapidly ailing daughter, she feels her own life slipping away too, 'ta vie a basculé — je l'ai bien vu qu'elle basculait parce que la mienne avec' (CME 41). This sense of feeling close to death is uttered once again by the mother who, in struggling with her grief in the immediate aftermath, reveals ' $J$ 'étais tout près de te rejoindre' (CME 129). When the death of Camille is officially pronounced at the hospital, Daull describes the news as resembling a violent corporeal attack on her own body, first 'le coup de hache' ( $C M E$ 46) and then like a bullet shooting through her (CME 47). This bullet continues to travel though her as she prepares for the autopsy and the funeral, and she longs to bleed and despairs at her resilience saying, 'J'attendais tranquillement de mourir, mais ça ne venait pas' (CME 56). Later, when the mother-narrator cuts her finger accidently, the desire to bleed is reiterated: ' $\mathrm{J}$ 'ai beaucoup saigné, $\mathrm{j}$ 'avais envie que ça ne s'arrête pas, que je me vide et qu'on n'en parle pas' ( $C M E$ 137). She compares herself to 'un mort vivant' $(C M E 83)$ and, indeed, she begins to take on the appearance of a corpse with 'mes mains $[\ldots]$ glacées' and 'mon visage pâle à faire peur' (CME 129). The narrator returns to this image of the mort vivant towards the end of the text when she writes, 'Je suis pénétrée de ta mort par toutes les fibres de mon corps, toutes mes veines sont calcifiées par la poudre de tes os' (CME 185). The process that we are witnessing here, Edelstein informs us, is one of maternal identification with the deceased child, a means of 'allying oneself with the dead by experiencing a reversible and symbolic death. ${ }^{20}$ Through the unconscious modelling of the mourner's physicality in the image of the one lost, the mourner is able to ensure that the attachment continues. As Edelstein explains, 'it is a way of holding on because identification with elements of the person means that he or she is never completely given up, but instead transformed into a part of one's self'. ${ }^{21}$ As well as the image of the

20. Edelstein, Maternal Bereavement, p. 21.

21. Edelstein, Maternal Bereavement, p. 22. 
bereaved mother as cadaver, there are also several allusions to the maternal body as wounded. The narrator describes her heart as 'crevé' (CME 12), 'déchiré' (CME 134) and refers to her loss as 'une plaie' (CME 128). Significantly, there is very specific mention of abdominal trauma in connection to the mother's grief: 'Je me souviens du précipice qui s'est ouvert dans mon ventre [...] et que dans mes entrailles une lave épaisse cloaquait' ( $C M E$ 157). It is possible to infer from this utterance of stomach pain an analogy with the womb, gestation and labour which strengthens our argument that maternal bereavement is replete with its own distinct set of embodied characteristics.

As the days following Camille's death unfold, Daull reveals that she no longer has any motivation to look after herself (CME 52) and writes to her daughter 'Ta maman est toute ralentie depuis que tu es morte' (CME 65). There is a very strong sense that the mother's body is going into shutdown in a mirroring, of sorts, of the illness that invaded the daughter. Maternal bereavement, as it is depicted in the novel, imprints on the mother not only internally but on the corporeal surface too. Daull feels that she has aged considerably almost overnight - again, it is as if she is willing her body to move to the end of its life-cycle - and, recalling Edelstein's assertion that the death of the child simultaneously brings about a dissolution of the mother, the mother-narrator has become almost unfamiliar to herself. She speaks of her 'bascule', 'transfert' and 'mutation' (CME 129) as a direct result of Camille's death and writes, 'Faut dire que ta maman a une sale tronche: poches, rides, cernes, le cheveu terne, kilos en moins, tous les plis vers le bas, et la démarche d'une très vieille dame' (CME 82-83). If Daull no longer recognizes her own appearance, or, rather, if she sees a woman who has been irremediably mutilated reflected back at herself and who only contains traces of her former self, the transformation of her language and voice is almost even more extreme, rendering her almost animallike in her grief: 'De mon corps sont sortis des sons que je ne connaissais pas. [...] Ça m'a fait peur' (CME 81). The narrator also reports repeatedly banging her head against a wall until it hurts, 
longing to feel pain (CME 81), in a bid to commune perhaps with the now deceased daughter's suffering. This sudden and virulent distortion of identity that is experienced by the mother in the aftermath of her daughter's death does not, it must be noted, extend to the father who, the narrator reveals, 'ne marque pas [...]. Il est toujours aussi beau' (CME 83). This observation by Daull is not meant to belittle her husband's grief in any way. On the contrary, the impact of the daughter's death on the father is relayed empathetically in the novel encompassing his anger, his confusion and his despair (CME 51). However, as readers we can discern from the dramatically different physical manifestations of grief as borne by mother and father, that maternal bereavement has its own distinct form that, as Edelstein argues, can be traced back to the gestational period of the infant in the mother's womb.

\section{Maternal bereavement: psychological manifestations}

As well as inscribing itself on the mother's body, Camille, mon envolée also bears witness to the psychological and emotional impact of maternal bereavement. Connected to the mother's physical suffering which, as I have argued, echoes the daughter's demise through illness, is the death drive that inhabits her mind too and is not simply limited to the body. Daull writes to her daughter that 'J'affleurais des régions troubles où te rejoindre dans la mort pouvait constituer une hypothèse valable' ( $C M E 25)$. She continues, revealing borderline suicidal tendencies, 'Je supporte mal l'idée de te survivre [...]. Je supporte mal l'idée de vivre encore au moins un temps long comme ta vie, seize ans. Et pourtant mon espérance de vie statistique m'y condamne à coup sûr' $(C M E 45)$. Living is now nothing more than a punishment for the mother who would rather, it would seem, join the daughter in death. In addition to these negative thoughts, Daull also experiences what might be termed hallucinations. Early on in the novel she describes how on awaking from a disrupted sleep just a few days after her daughter's death, she finds her husband by her 
bedside and is thrust into a state of delirium saying, 'Tout ce que je voyais dans la figure de ton père $[\ldots]$ c'étaient tes yeux à toi. Je hurlais entre deux sanglots qu'il te ressemblait trop [...]. Je l'appelais Camille. Lui voulait appeler les pompiers...' (CME 25). In other instances, Daull has the sensation that 'tu [Camille] nous donnes un signal, que tu viens faire coucou, que tu viens te glisser dans ce quotidien au chagrin géant (CME 137). According to Klass (2010), seeing, hearing and sensing the presence of dead children is often part of the daily reality for bereaved parents. ${ }^{22}$ They are phenomena that indicate interaction with the inner representation of the dead child, but they are not easily socially integrated. While such behaviour could be exhibited by either parent, in the case of Camille, mon envolée, it would seem that it is only the mother who is affected.

It is worth speculating at this stage not simply on the specificity of maternal grief, but also the uniqueness of the mother-daughter relationship and the implications of the death of a daughter as opposed to a son for the negotiation of maternal bereavement. The very particular symbiosis between mother and daughter has been firmly established by feminist theory. One of the earliest second-wave feminist discussions of the mother-daughter relationship can be located in Le deuxième sexe where de Beauvoir alerts us to the idea of the daughter as extension of the mother. ${ }^{23}$ This image resurfaces in Nancy Chodorow's The Reproduction of Motherhood and again in Adrienne Rich's $O f$ Woman Born where Rich draws our attention to the possibility of a pre-verbal and subliminal knowledge between two alike bodies that cannot be matched by any other human relationship. ${ }^{24}$ What Rich is describing is a mother-daughter osmosis that also features predominantly in two of Luce Irigaray's essays, $E t$

22. Dennis Klass, 'The Deceased Child in the Psychic and Social Worlds of Bereaved Parents', p. 155.

23. Simone de Beauvoir, Le deuxième sexe (Paris: Gallimard, 1949).

24. Nancy Chodorow, The Reproduction of Mothering (Berkeley: University of California Press, 1978); Adrienne Rich, Of Woman Born (New York: Norton Press, 1976). 
l'une ne bouge pas sans l'autre and Le corps-à-corps avec la mère. ${ }^{25}$ In Camille, mon envolée, there is much to suggest a corollary between the specific loss of a daughter and the embodied nature of the ensuing maternal bereavement. The narrator refers to the re-incorporation of the daughter into the maternal body and the recreation of a symbiosis. First of all, Daull informs us that she mostly writes about and to her daughter while in the bath. On one level, the bath is simply a reminder of the daughter who used to spend hours there bathing, relaxing and dreaming ( $C M E$ 130). On a more symbolic level, however, the bath as an enclosed space with its engulfing water, and, furthermore, the blood that on occasion the narrator imagines she can see strewn across the tiles, is highly reminiscent of the birthing womb, the original space of the mother-daughter dyad. In addition to this, there is a sense that the mother is becoming the daughter through her bereavement. Daull writes, 'J'ai pris seize ans, tes seize ans' (CME 83), she proclaims and later 'mon sang aura désormais toujours 16 ans' (CME 51). Mother and daughter are frequently presented in the text as one and the same, with the author stating, 'Je vivrai ta vie', and going on to say, 'Tu me regarderas et me guideras, selon ce tu que fus, ce que tu promettais [...]. Je vais exister par en dessous, par soustraction, par extension de toi' (CME 51). These are not the only references that we encounter in Camille, mon envolée to a motherdaughter synergy being a key facet of maternal bereavement. At another moment, Daull speculates:

Dans mes rêves peut-être tu vas devenir comme ma mère. Je serai ton enfant. En écrivant ça, chaton, je crois en fait c'est en train d'arriver. Oui. Je deviens ton enfant; $\mathrm{j}$ 'ai peur quand tu n'es pas là et je sens que tu me protèges. (CME 113)

25. Luce Irigaray, Et l'une ne bouge pas sans l'autre (Paris: Editions de Minuit, 1979) and Le corps-à-corps avec la mère (Montreal: Editions de la Pleine Lune, 1981). 
With this assertion, it becomes clear that, so intense is the cathexis, the roles of mother and daughter are quasi-interchangeable. What this latter quotation reveals then, is that that by psychically positing herself as the child and the deceased daughter as the mother, Daull is subconsciously facilitating a resurrection of sorts of the daughter and sacrificing her own identity in favour of prolonging the daughter's, an act which could also help to alleviate any maternal guilt felt at having failed to protect her child from death. Further supporting this idea of mother-daughter substitution in bereavement is the unexpected return of menstruation for the narrator following an extended period of amenorrhea and which she describes as 'un sang de jeune fille' (CME 182).

The final aspect of the psychological manifestations of maternal bereavement in Camille, mon envolée that I would like to consider is that of dissociation. Dissociation, in psychiatric studies of grief (and more generally), is defined as a disruption of identity and perception. It encompasses an array of responses, including a sense of detachment from oneself and alternations in the experience of place. It is generally experienced immediately after a traumatic loss. ${ }^{26}$ While dissociation may be unsettling to observe, it is also, especially in the impact phase of grief, a way of coping and remaining calm and a phenomenon that will generally resolve itself over time. ${ }^{27}$ In the case of Daull, the death of her daughter causes her to experience a sensation of doubling. She appears to have transcended her own corporeal boundaries and observes herself completing actions from the outside as if she is 'other' to the self. ${ }^{28}$ She hears her voice and it is unfamiliar to her, as if someone else is speaking (CME 128). When

26. Eric Bui et al., 'Periloss Dissociation, Symptom Severity, and Treatment Response in Complicated Grief', Journal of Depression and Anxiety, 30.2 (2013), 123-28 (p. 124).

27. Parkes and Prigerson, Bereavement, p. 271.

28. We are reminded here of the point about loss of self, disintegration of identity through grief. We have already discussed how the mother no longer recognizes herself following the daughter's death and this doubling is a further manifestation of the collapse of maternal subject. 
recounting the events of the funeral parlour, the overriding experience for the narrator is one of total detachment and disembodiment, as when she states, 'je me suis vue me décoller du banc, traverser la petite cour, monter les trois marches, comme aimantée' (CME 171). And yet at the same time, despite her disorientation, the narrator is capable of displaying insight into her behaviour and awareness of the defence mechanism that is inherent to disassociation in the wake of trauma: 'Ce dédoublement suspect préfigure sans doute le mode selon lequel il sera possible de ne pas mourir à ta suite, ce que j'appelle aujourd'hui ma vie mimée' (CME 128).

\section{Maternal bereavement: social implications}

Having discussed the direct impact of child loss on the mother and its distinct physical and psychological manifestations, I will now turn to the wider social implications of maternal bereavement in terms of the expectations of and reactions to the grieving mother. It becomes quickly evident in the text that the mother's entourage, both close and extended, is deeply uncomfortable with the spectacle of maternal grief. When in her company, they only indirectly refer to Camille's death (CME 176) or, worse, try to avoid talking about the topic at all even though this is what would help the bereaved mother best. The author says, 'Moi j'ai toujours besoin de parler de toi, de comment t'es plus là' (CME 55) but instead she finds herself up against what she perceives to be 'une foule ignorante, indifférente' (CME 134). The mother-narrator continues:

Tu sais, les gens sont terriblement gênés [...]. Ils ont des formules qui bégayent d'euphémismes maladroits. Ils disent: le 'drame', la 'tragédie', le 'grand malheur qui vous arrive' [...]. Je leur dis de simplifier, d'appeler les choses par leur nom, de dire: 'La mort de Camille'. (CME 176) 
This experience of an unshared and, indeed, unshareable pain is common among parents who lose a child. As Klass notes, 'the pain they experience is not felt within their community. It often seems to them that neither the child nor the child's death has social reality, for they find that people do not mention the child's name in their presence'. ${ }^{29}$

More specifically, however, it would seem that it is the mother's trauma that is most disquieting and causes people to turn away, not knowing how to respond to the spectacle of maternal grief. The mother-narrator remarks, 'J'ai l'impression que ceux qui savent me parlent avec toutes sortes d'étranges égards, une autre voix, d'autres mots - et que ceux qui ne savent pas me regardent comme un zombie' (CME 82). Subsequently, she feels obliged to hide the more visceral manifestations of her loss, seeking refuge in 'des coins isolés où je puisse hurler ma douleur' (CME 81), and observes that her grief is 'un truc insupportable: une mère qui vient de voir sa fille de 16 ans dans son cerceuil' (CME 171). As Jacqueline Rose comments, 'a mother's loss $[\ldots]$ is the truly unbearable torment, too glaring a testimony to the cruelty of the modern world, and therefore impossible to contemplate'. ${ }^{30}$

It is in its probing of the reluctant societal encounter with maternal bereavement that Camille mon, envolée offers one of its most subversive strands. Beyond simply confronting the reader with the mere occurrence of an untellable and unspeakable trauma, is the way in which the text, at certain points, disrupts the normative image of the grieving mother as perpetual mater dolorsa. As Rose notes, there is a certain expectation for the grieving mother to adhere to a particular imago that is in line with the familiar scripts of the Pietà or the Virgin Mary. The bereft mother, Rose informs us, 'must be noble and her agony redemptive $[\ldots]$. What the pain of mothers must never

29. Klass, 'The Deceased Child', p. 152

30. Jacqueline Rose, Mothers: An Essay on Love and Cruelty (London: Faber and Faber, 2018), p. 11. 
expose is a viciously unjust world in a complete mess'. ${ }^{31}$ Rose questions 'how often the grief of a mother [is] allowed to wander outside the frame of the requisite pathos? ${ }^{32}$ and concludes that a mother can suffer as long as this grief is performed appropriately without disrupting prescribed societal and cultural notions of 'good' maternal grief. From the outset, the bereavement trajectory of the mother-narrator in Camille, mon envolée deconstructs the supposed existence of a proper and socially acceptable script of maternal mourning. Indeed, the mother-narrator makes a determined promise to her daughter to write 'franc, droit, lumineux' (CME 12) rather than in compliance with standard models of mourning: 'Je vais forcer mes mots pour qu'ils échappent au sirop du deuil un peu gluant, poème pompeux, élégie larmoyante' ( $C M E$ 12). Subsequently, alongside the more predictable emotions of grief are what the mother-narrator labels her 'mauvaises pensées' which invade her mind and are out of her control 'sans aucun filtre de pudeur, avec aplomb, avec cynisme' (CME 86). These 'mauvaises pensées' are the source of an acerbic humour that one would not expect to encounter in a novel that is about the devastating loss of a daughter. They lead her to speculate on the ways in which she might actually be better off now without a daughter: 'Pas de gendre infect, de petits-enfants mal élevés, de déprimés à éponger en cas d'échec à Sciences Po ou de divorce à 30 ans... Pas d'insomnies tordues d'angoisse à attendre ton retour de boîte de nuit [...]' (CME 57). In a similar tone, she makes a joke to the neighbours when giving them a spare key, saying, 'Voici celle de Camille. Elle ne lui manquera plus' (CME 124). This incongruous humour, the mother reveals, is a defence mechanism of sorts and helps her to survive on a daily basis 'comme si ça faisait passer la pilule' (CME 57) and to conserve a space for herself 'sans m'y effondrer' (CME 86). However, it is also a trigger for feelings of maternal guilt as she is aware that these feelings are a deviation from

31. Rose, Mothers, p. 12.

32. Rose, Mothers, p. 14. 
normative maternal mourning. When experiencing an influx of 'mauvaises pensées' in relation to her daughter she laments, 'Je calculais tout ça en me frottant les mains. C'était horrible' (CME 57). But these 'mauvaises pensées' are an important part of the work of mourning for the narrator and their osmosis into the text serves as a counterpoint to the more traditional and restrictive image maternal purity in bereavement.

This brings us now to a discussion of the status of the bereaved mother in society. In addition to the reluctance to listen to and bear witness to the suffering mother is a refusal to accord her any authentic role moving forward now that she is without child. The loss of the child (which in the case of Camille, mon envolée concerns an only child) brings about a disruption to maternal identity and causes a shift in position from mother to non-mother. As the narrator observes in relation to herself:

C'est quand même bizarre d'être devenue cette femme dont le petit carnet au fond du sac à main, au lieu de renfermer l'adresse du kiné, un succès de librairie ou l'adresse mail d'une copine, contient des coordonnées d'un funérarium, d'une chambre mortuaire et d'un service d'autopsies. (CME 130)

Even more disorienting, however, than this sensation of a disrupted maternal identity, is the experience of an entirely erased identity. Just as there is no language of mourning that can authentically capture parental grief, nor is there any term to describe their altered roles in society: 'Nous n'avons pas de nom. Nous ne sommes ni veufs ni orphelins. Il n'existe pas de mot pour désigner celui ou celle qui a perdu son enfant' (CME 83). This feeling of being an un-nameable outcast or, as Elaine Tuttle Hansen describes it, 'a logical impossibility', ${ }^{33}$ is exacerbated in the case of the mother whose

33. Elaine Tuttle Hansen, Mother Without Child (Berkeley: University of California Press, 1997), p. 26 
identity, as a result of societal constructions of motherhood, is more closely entwined with that of the child. As Tuttle Hansen notes, 'the loss or threatened loss of the other member of the dyad, the child, has often been used to define and stabilise a particularly disabling meaning of mother rather than to open motherhood up to analysis' ${ }^{34}$ Subsequently, the mother of Camille, mon envolée experiences 'un sentiment de dissidence, d'étrangeté, de non-participation' (CME 82) now that she has become a mother without a child. She feels maimed and purposeless without her child, as if her life narrative has been stunted. It is not surprising that many of her pleas to Camille during the latter's illness are related to the future and the need for the daughter to survive in order to concomitantly secure the mother's continuity.

In addition, another way in which Camille mon envolée diverges once again in terms of its non-prescriptive image of the mourning mother is in the latter's determination to live once she has managed to emerge from the immediate trauma of the daughter's death. If we are surprised by the moments of humour in the text, the so-called 'mauvaises pensées', we are probably equally confounded by other actions on the part of the mother, such as her decision to proceed with Christmas festivities mere hours after Camille's passing, how quickly she clears out Camille's bedroom or, rather, 'neutralises' it (CME 97), and her early return to work (as an actress). On the one hand, this is partly a mere automatic response, 'un mouvement hyperactif, une hystérie de choses-à-faire, une occupation maniaque du temps, un remplissage de chaque seconde pour ne pas sombrer, pour ne pas mourir comme toi' (CME 71). On the other hand, it is also indicative of a subject - albeit one shattered by trauma - who is slowly attempting to find a way to reconstitute a new self. A self that will, of course, always be marked by this loss, but which will be able to forge ahead in life, even if it is as nothing more than 'une machine à survivre' (CME 137) in the early stages.

34. Tuttle Hansen, Mother Without Child, p. 22 
Scriptotherapy and the re-membering of the maternal subject

This leads us now to the final section of the article which will consider Camille, mon envolée as an act of engagement with scriptotherapy. The potential of scriptotherapy (or writing therapy) for improving psychological wellness and creating a sense of coherence out of chaos has an established and well-documented history. ${ }^{35}$ Scriptotherapy allows the patient/victim/writer to distil traumatic experiences and break them into more understandable packages. For Suzette Henke, to whom the coining of the term scriptotherapy has been ascribed, it is the distinct practice of writing out and through trauma that facilitates recovery and reintegration. ${ }^{36}$ Public inscription of private testimony is a means of healing and the process of rehearsing and re-enacting the trauma narrative is a way of 'reconstituting the beleaguered subject and re-membering the self shattered by traumatic experience'. ${ }^{37}$ This desire to write through and out of bereavement is present from the outset in Camille, mon envolée. At first, the writing process is quite clearly borne from a need to keep the daughter close. The latter's death has been so sudden and unexpected that the mother-narrator has not yet had the time to even absorb the course of recent events never mind enter into the stage of letting go of the daughter. She states, 'je n'ai qu'une envie, c'est [...] de continuer à écrire ce texte. D'être avec toi, donc. Écrire, c'est te prolonger' (CME 76). However, as the text unfolds, this desire to stay alongside, and in constant conversation with, the daughter shifts, it seems, to a stage that one might describe as

35. See Janella D. Moy, 'Reading and Writing One's Way to Wellness: The History of Bibliotherapy and Scriptotherapy', in New Directions in Literature and Medicine Studies, ed. by Stephanie M. Hilger (London: Palgrave Macmillan, 2017), pp. 15-30.

36. Suzette A. Henke, Shattered Subjects: Trauma and Testimony in Women's Life-Writing (New York: St. Martin's Press, 2000).

37. Henke, Shattered Subjects, p. 144. 
calmness or acceptance and, finally, a readiness to emerge from the suffering of the present and enter into a new phase of existence without the daughter. The mother-narrator's anger at her untimely loss appears to subside and there is no urge to seek retribution or explanations because it is deemed pointless: 'Il n'y aura pas de fin mot. De toute façon je n'éprouve aucun désir d'attaquer quoi que ce soit: ni Dieu, ni le destin, ni la médecine' (CME 91). ${ }^{38}$ Towards the close of the text, this shift becomes even more pronounced and the mother-narrator reaches a stage in the writing where she now feels that it is time to move forward. On the one hand, this is because there is no other choice, she is condemned to live on: 'Je continue. J'avance. Je n'ai rien d'autre à faire puisque ce médicament n'existe pas ' $(C M E$ 126). On the other hand, there is a sense that the mothernarrator may have reached a point of scripto-catharsis where she is able to leave the text and, by connection, the daughter, behind. There is certainly an air of strength when she announces her leave-taking though the completion of the text while simultaneously confessing that it will be a difficult departure:

Maintenant il va falloir finir d'écrire; écrire était encore un tremblement, un spasme de ta vie dans me mots. J'ai peur de te laisser, mais je me l'impose. Ne pas pleurnicher quatre ans quand tu t'es battue quatre jours. Tu as été si courageuse que mon courage sera dans ce tout prochain point final. (CME 185)

38. In an interview with Bernard Lehut for RTL, Sophie Daull elaborates on her decision not to pursue any legal redress for Camille's death even though there may well have been a case for medical negligence. If the bacteria had been detected earlier and Camille had been prescribed the proper antibiotics there is a chance that could have survived. However, Daull states that she did not wish to 'ajouter de la haine au chagrin' and, therefore, preferred to opt for 'un geste poétique' (the writing of her text) as a form of retribution for the loss of and as a gift to her daughter. See 'Camille, mon envolée, le livre poignant de Sophie Daull', RTL, 1 December 2015, <https://www.rtl.fr/culture/musique/camille-mon-envolee-le-livre-poignant-de-sophiedaull-7780692697> [accessed 2 January 2019]. 
That this strength is modelled on her daughter's courage during her illness is a testimony of sorts to Camille, an acknowledgement of a final exchange between mother and daughter that will allow the mother to move on, to continue to exist in spite of her shattered self. The writing process, however, has not only facilitated the reconstitution of the fragmented mother, but also the recreation of an alternative version of the daughter, a poetic and transcendental figuration whose endurance now has the potential to be infinite. When reflecting back on Camille, mon envolée in her second novel, La Suture, Daull observes with pride and assurance, 'Camille — c'est un livre maintenant. Un être de papier'. ${ }^{39}$

Maynooth University

39. Daull, La Suture, p. 13 (emphasis in original). 